\title{
Baseline SUV Range for Liver and Blood Pool in Patients Undergoing F-18 Fluorodeoxyglucose Positron Emission Tomography/Computed Tomography
}

\begin{tabular}{|c|c|}
\hline \multicolumn{2}{|c|}{$\begin{array}{l}\text { (1) Yasemin Parlak, (D) Didem Göksoy, (D) Gözde Mütevelizade, (D) Gül Gümüşer, (D) Elvan Sayit } \\
\text { Manisa Celal Bayar University Faculty of Medicine, Department of Nuclear Medicine, Manisa, Turkey }\end{array}$} \\
\hline ABSTRACT & ÖZ \\
\hline $\begin{array}{l}\text { Introduction: The aim of the study was to define the baseline } \\
\text { SUV } \\
\text { max range in the liver and blood pool of patients undergoing } \\
\text { fluorodeoxyglucose-positron emission tomography/computed } \\
\text { tomography (FDG-PET/CT) imaging. }\end{array}$ & $\begin{array}{l}\text { Giriș: Çalıșmanın amacı, florodeoksiglukoz-pozitron emisyon } \\
\text { tomografi/bilgisayarlı tomografi görüntüleme (FDG-PET/BT) } \\
\text { yapılan hastaların karaciğer ve kan havuzundaki bazal SUV } \\
\text { aralığının tanımlanmasıdır. }\end{array}$ \\
\hline $\begin{array}{l}\text { Methods: Five hundred and thirty-one patients ( } 264 \text { females, } \\
267 \text { males; mean age: } 59.6 \pm 13.4 \text { years) who were admitted } \\
\text { to our department for PET/CT imaging before treatment } \\
\text { were included in the study. Patient preparation, acquisition } \\
\text { parameters and reconstruction protocols were standardized for } \\
\text { all patients prior to PET/CT imaging. The mean serum glucose } \\
\text { levels and mean age of the patients were calculated. These } \\
\text { patients were divided into } 10 \text { groups as esophagus, stomach, } \\
\text { colon, rectum, larynx, lung, breast, endometrium, ovarian } \\
\text { cancers and lymphoma. } 2 \mathrm{D} \text { region of interests were plotted to } \\
\text { calculate the mean SUV values in the right lobe of the liver and }\end{array}$ & $\begin{array}{l}\text { Yöntemler: Bölümümüze tedavi öncesi PET/BT görüntüleme } \\
\text { için gelen } 531 \text { hasta ( } 264 \text { kadın, } 267 \text { erkek; yaş ortalaması } \\
59,6 \pm 13,4 \text { yıl) çalışmaya dahil edildi. Tüm hastalar için PET/BT } \\
\text { görüntüleme öncesi hasta hazırlığı, aküzisyon parametreleri } \\
\text { ve rekonstrüksiyon protokolleri standardize edildi. Hastaların } \\
\text { ortalamaserumglukozseviyeleriveyaşortalamaları hesaplandı. } \\
\text { Bu hastalar özofagus, mide, kolon, rektum, larinks, akciğer, } \\
\text { meme, lenfoma, endometrium ve over kanserleri olmak üzere } \\
10 \text { gruba ayrıldı. Karaciğerin sağ lobuna ve kan havuzu için } \\
\text { aort kavisine ortalama SUV değerlerinin hesaplanabilmesi için } \\
2 \text { boyutlu ilgi alanı bölgeleri çizildi. }\end{array}$ \\
\hline $\begin{array}{l}\text { the aortic arch for the blood pool. } \\
\text { Results: Normal Gaussian distributions of mean SUV changes } \\
\text { for liver and blood pool were obtained. Mean SUV } \text { max }_{\text {and SUV }} \text { mean } \\
\text { values for liver were } 2.73 \pm 0.22 \text { and } 2.34 \pm 0.16 \text {, respectively, } \\
\text { and } 1.80 \pm 0.2 \text { and } 1.57 \pm 0.14 \text { for blood pool, respectively. }\end{array}$ & 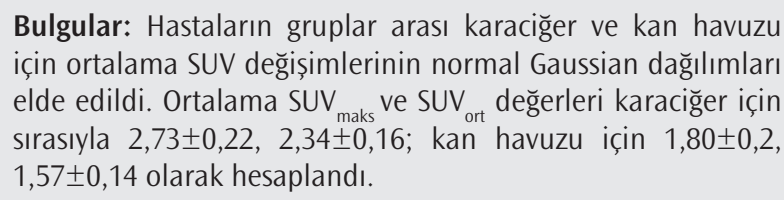 \\
\hline $\begin{array}{l}\text { Conclusion: It was concluded that the obtained SUV ranges } \\
\text { may provide ease of application in the clinic in evaluating } \\
\text { qualitative tumor response and comparing tumor/background } \\
\text { ratios in cancer patients. }\end{array}$ & $\begin{array}{l}\text { Sonuç: Elde edilen SUV aralıklarının kanserli olgularda } \\
\text { kalitatif tümör cevabı değerlendirmede ve tumör/background } \\
\text { oranlarını kıyaslamada klinikte uygulama kolaylığı } \\
\text { sağlayabileceği kanaatine varıldı. }\end{array}$ \\
\hline Keywords: PET/CT, SUV measurement, tumor background ratio & $\begin{array}{l}\text { Anahtar Kelimeler: PET/BT, SUV ölçümü, tümör background } \\
\text { oranı }\end{array}$ \\
\hline
\end{tabular}

\section{Introduction}

F-18 fluorodeoxyglucose positron emission tomography/computed tomography (F-18 FDG PET/CT) is increasingly used in tumor diagnosis, staging, treatment response evaluation, and radiotherapy planning. Combined PET/CT devices provide both metabolic information from F-18 FDG PET and anatomical information from CT in a single imaging (1).
The most important difference of PET/CT from radiological imaging methods such as direct radiographs and $\mathrm{CT}$, which provides structural information about various diseases, is that it provides functional information. In functional imaging, it is possible to monitor tissue perfusion, glucose metabolism and receptor activities by using appropriate methods and imaging agents (2). 
FDG studies constitute the majority of PET applications in the world. FDG, just like D-glucose, passes through the cell membrane and phosphorylated to the FDG-6-phosphate by the enzyme hexokinase. However, after this step, it cannot be catabolized and accumulates in the cell. Tissues with increased glucose utilization and metabolism appear as hypermetabolic foci in PET images with higher concentrations than normal tissues, and tissues with reduced glucose metabolism appear as hypometabolic foci in PET images with lower concentrations than normal tissues.

FDG, which is transported into the cell via the glucose transporter proteins from the circulation, shows a biodistribution quite similar to glucose in the body. The brain holds very intense FDG due to the use of high amounts of glucose in the gray cortex. FDG uptake in the heart changes in relation to the patient's fasting. FDG uptake is more pronounced as glucose use increases in satiety, and it decreases in longterm hunger. The liver maintains a lower density and homogeneous FDG. Gastric and intestinal involvement varies according to the patient. Bone and muscles maintain high FDG in case of activation.

One of the most important features of PET is the ability to digitize the results. The most commonly used term is the standardized uptake value (SUV). It is particularly suitable for monitoring response to treatment. It is a semiquantitative parameter. If the dose is evenly distributed throughout the body, the SUV should be approximately 1 everywhere. The SUV is therefore a relative uptake measurement, a unitless value and reflects the ratio. SUV may vary with factors such as patient imaging time, partial volume effects, reconstruction parameters, and attenuation correction methods. The SUV is obtained by dividing the mean activity $(\mathrm{mCi} / \mathrm{mL})$ in a region of interest (ROI) to the injected dose $(\mathrm{mCi} / \mathrm{kg})(2,3)$.

Foci with non-physiological and increased FDG uptake compared to background activity are evaluated in the interpretation of images. SUV> 2.5 may indicate that the lesion is hypermetabolic. These hypermetabolic foci do not always mean that there is a tumoral lesion (3). Generally, lesions with higher involvement than blood pool (BP) suggest malignancy. Semiquantitative calculation of tumor metabolism is based on the ratio of F18-FDG uptake to lesion involvement in reference sites such as BP, mediastinum, liver and cerebellum. These are the most commonly used tissues (3-5).
The aim of this study was to define the F-18 FDG uptake range for BP and liver from these reference regions before treatment of patients with different diagnoses.

\section{Methods}

A total of 531 patients (264 females and 267 males) who were admitted Nuclear medicine department for PET/CT imaging before treatment were included in the study. Ethics committee approval was not received because our study was a retrospective study. Written consent was obtained from all patients. Patients were divided into 10 groups according to the diagnosis. Patient groups and number of patients are given in Table 1. Age (years), weight $(\mathrm{kg})$, height $(\mathrm{cm})$ and serum glucose levels $(\mathrm{mg} / \mathrm{dL})$ of all patients were recorded. Body mass index (BMI) values were calculated (Table 2). Fasting blood glucose levels were measured before F-18 FDG injection following a 5-hour fasting and 4.2 $\mathrm{MBq} / \mathrm{kg}$ F-18 FDG injection was performed in patients with a glucose level below $200 \mathrm{mg} / \mathrm{dL}$. After the injection, the patients were taken to special waiting rooms to rest. After an average of 60 minutes, the patient was positioned in the supine position with the arms up from the vertex to the proximal thigh, and low-dose CT (120 kVp and $80 \mathrm{mAs}$ ) and PET (Philips True Flight Select model) images were obtained. CT data were used for attenuation correction. Patient preparation, acquisition protocols and reconstruction parameters were standardized prior to $\mathrm{PET} / \mathrm{CT}$ imaging for all patients. OSEM reconstruction algorithm was used with reconstruction parameters of 3 iterations and 33 subsets for

\begin{tabular}{|l|l|l|}
\hline Table 1. Number of patients by diagnosis & \multicolumn{1}{l|}{} \\
\hline Group & Diagnosis & Patient number \\
\hline 1 & Esophagus cancer & 50 \\
\hline 2 & Stomach cancer & 51 \\
\hline 3 & Colon cancer & 49 \\
\hline 4 & Rectum cancer & 54 \\
\hline 5 & Larynx cancer & 55 \\
\hline 6 & Over cancer & 50 \\
\hline 7 & Endometrium cancer & 56 \\
\hline 8 & Lung cancer & 57 \\
\hline 9 & Breast cancer & 56 \\
\hline 10 & Lymphoma & 53 \\
\hline
\end{tabular}

Table 2. Age, fasting blood glucose, injection dose and body mass index according to patient groups

\begin{tabular}{|l|l|l|l|l|}
\hline Group & Age (years) & Fasting blood glucose $(\mathbf{m g} / \mathbf{d L})$ & Activity (MBq) \\
\hline 1 & $61 \pm 13.4$ & $96 \pm 20.3$ & $233 \pm 33$ \\
\hline 2 & $60.1 \pm 13.1$ & $96.0 \pm 17.2$ & $244.2 \pm 22.2$ \\
\hline 3 & $61.9 \pm 12.1$ & $105 \pm 27.1$ & $246.1 \pm 23.7$ & $23 \pm 5.3$ \\
\hline 4 & $62.5 \pm 13.8$ & $103.3 \pm 18.9$ & $241.6 \pm 25.2$ & $27.2 \pm 5.3$ \\
\hline 5 & $64.9 \pm 10.2$ & $97.1 \pm 20.3$ & $242.7 \pm 28.5$ & $25.3 \pm 5.8$ \\
\hline 6 & $64.2 \pm 9.6$ & $101.5 \pm 25.6$ & $235.7 \pm 22.9$ \\
\hline 7 & $52.9 \pm 11.3$ & $99 \pm 16.1$ & $250.5 \pm 35.9$ \\
\hline 8 & $61.2 \pm 12.1$ & $101.2 \pm 24.5$ & $262.7 \pm 38.2$ \\
\hline 9 & $57.1 \pm 13.6$ & $101.5 \pm 20$ & $252.7 \pm 31.8$ \\
\hline 10 & $50 \pm 16.9$ & $99 \pm 22$ & $247.9 \pm 36.3$ \\
\hline MBq: megabecquerel & & & $32.1 \pm 6.3$ \\
\hline
\end{tabular}


all patients. The lesion and high activity ROIs were removed from the axial fusion images obtained after imaging and 2D ROls were plotted to calculate the average SUV in the right lobe of the liver (Figure 1) and aortic arch for BP (Figures 1 and 2). SUV $V_{\text {max }}$ and SUV $V_{\text {mean }}$ in the area related to the plotted ROIs were calculated and recorded.

\section{Statistical Analysis}

The data obtained were recorded into SPSS 15.0 data analysis program, and normal Gaussian distributions of mean SUV changes between the groups for BP and liver were obtained.

\section{Results}

SUV changes for BP and liver between groups were calculated and shown in Table 3. According to the results, mean SUV ${ }_{\text {max }}$ and SUV $\mathrm{V}_{\text {mean }}$ of all patients were $2.74 \pm 0.43$ and $2.34 \pm 0.41$ for liver, respectively, and $1.82 \pm 0.37$ and $1.58 \pm 0.33$ for BP, respectively. The SUVs obtained separately for each group are shown in Table 3 and the graphs are shown in detail in Figure 3. Using SPSS 15.0, ANOVA test was performed to determine statistical difference between mean SUVs for liver and

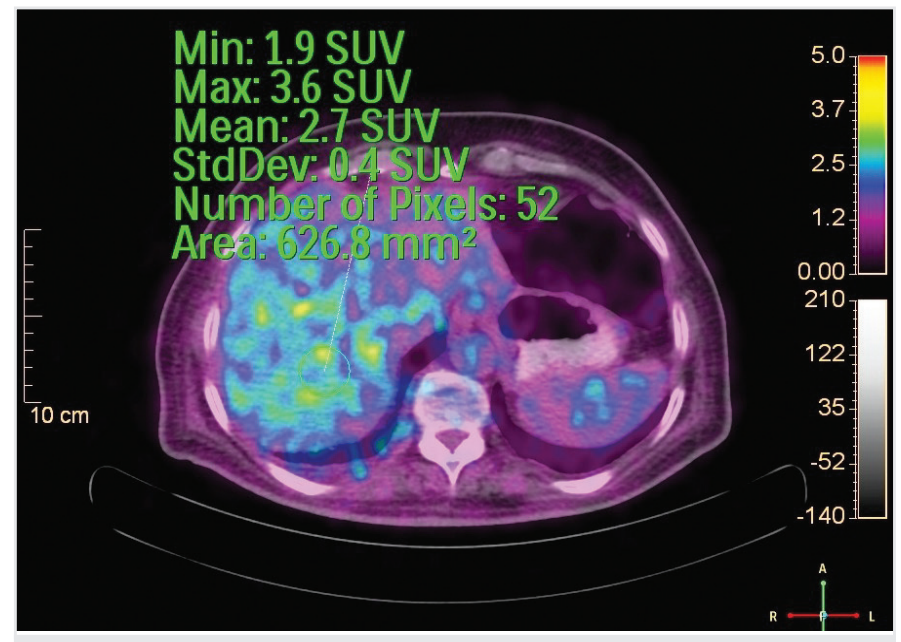

Figure 1. 2D ROI plotted on right lobe of liver

Min: minimum, max: maximum, SUV: standard uptake value, StdDev: standard deviation, ROI: region of interest
BP between the groups. Significant differences were found between the groups according to statistical results. The highest SUV was found in patients with endometrial carcinoma $\left(S_{U} V_{\text {max }}: 3.2 \pm 0.33\right.$ and $S U V_{\text {mean }}$ : $2.7 \pm 0.33$ for liver; SUV ${ }_{\max }: 2.22 \pm 0.39$ and SUV ${ }_{\text {mean }}: 1.86 \pm 0.34$ for BP). Liver SUV $_{\max } / B P$ SUV $_{\max }$ ratios of all groups were determined and this ratio was calculated as an average of 1.5 (Table 3). Table 4 shows the $p$ values expressing inter-group significance.

\section{Discussion}

$\mathrm{PET} / \mathrm{CT}$ is a highly useful hybrid modality for imaging, tumor diagnosis, staging, and evaluation of treatment response. Its most important advantage is its ability to provide quantitative results that provide the clinician with the most benefit in reporting. The most commonly used quantitative parameter is the SUV. It is frequently used especially in the evaluation of response to treatment. For these reasons, it is clinically useful to know the SUV variation range in F-18 FDG PET/CT imaging. In this study, a range was created for SUV ${ }_{\max }$ and mean values of the two areas (liver and BP), which are considered as reference.

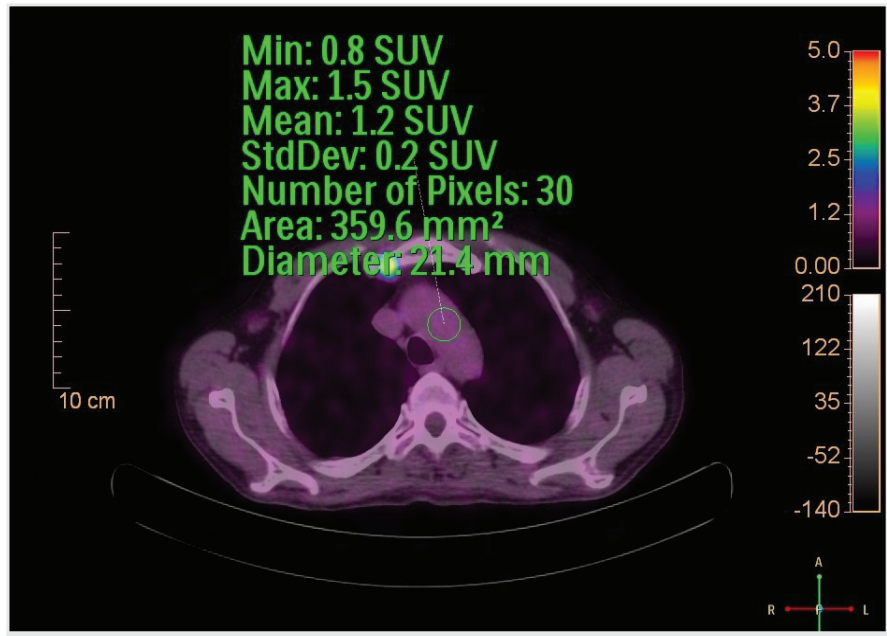

Figure 2. 2D ROI plotted on aortic arch

Min: minimum, max: maximum, SUV: standard uptake value, StdDev: standard deviation, ROI: region of interest

Table 3. Standard uptake value changes for liver and blood pool

\begin{tabular}{|c|c|c|c|c|c|}
\hline Diagnosis & $\begin{array}{l}\text { Liver } \\
\text { SUV }\end{array}$ & $\begin{array}{l}\text { Liver } \\
\text { SUV }_{\text {mean }}\end{array}$ & $\begin{array}{l}\text { BP } \\
\text { SUV }\end{array}$ & $\begin{array}{l}\text { BP } \\
\text { SUV }\end{array}$ & $\begin{array}{l}\text { Liver/BP } \\
\text { SUV }_{\max }\end{array}$ \\
\hline Esophagus cancer & $2.55 \pm 0.3$ & $2.30 \pm 0.37$ & $1.70 \pm 0.27$ & $1.54 \pm 0.24$ & 1.50 \\
\hline Stomach cancer & $2.7 \pm 0.3$ & $2.27 \pm 0.33$ & $1.69 \pm 0.27$ & $1.48 \pm 0.26$ & 1.59 \\
\hline Colon cancer & $2.62 \pm 0.35$ & $2.26 \pm 0.30$ & $1.65 \pm 0.27$ & $1.44 \pm 0.23$ & 1.58 \\
\hline Rectum cancer & $2.67 \pm 0.41$ & $2.36 \pm 0.33$ & $1.77 \pm 0.26$ & $1.56 \pm 0.29$ & 1.50 \\
\hline Larynx cancer & $2.89 \pm 0.48$ & $2.43 \pm 0.46$ & $1.97 \pm 0.39$ & $1.66 \pm 0.37$ & 1.47 \\
\hline Over cancer & $2.8 \pm 0.47$ & $2.43 \pm 0.5$ & $1.84 \pm 0.35$ & $1.67 \pm 0.40$ & 1.52 \\
\hline Endometrium cancer & $3.2 \pm 0.33$ & $2.7 \pm 0.33$ & $2.22 \pm 0.39$ & $1.86 \pm 0.34$ & 1.44 \\
\hline Lung cancer & $2.6 \pm 0.37$ & $2.2 \pm 0.31$ & $1.77 \pm 0.3$ & $1.48 \pm 0.28$ & 1.47 \\
\hline Breast cancer & $2.82 \pm 0.39$ & $2.43 \pm 0.36$ & $1.94 \pm 0.30$ & $1.67 \pm 0.30$ & 1.45 \\
\hline Lymphoma & $2.45 \pm 0.4$ & $2.0 \pm 0.40$ & $1.58 \pm 0.34$ & $1.38 \pm 0.32$ & 1.55 \\
\hline Mean & $2.74 \pm 0.43$ & $2.34 \pm 0.41$ & $1.82 \pm 0.37$ & $1.58 \pm 0.33$ & 1.50 \\
\hline
\end{tabular}


Table 4. Intergroup p values

\begin{tabular}{|c|c|c|c|c|c|c|c|c|c|c|}
\hline Malignancy & 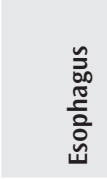 & 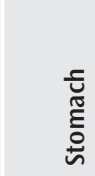 & $\frac{\Xi}{0}$ & $\underset{\mathscr{\varpi}}{\underline{\Xi}}$ & $\sum_{\frac{J}{J}}^{x}$ & ठ̀ & 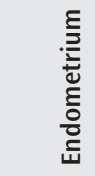 & $\stackrel{\infty}{\Xi}$ & 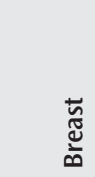 & 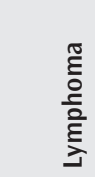 \\
\hline Esophagus & - & 0.6 & 0.07 & 0.8 & 0.00 & 0.04 & 0.00 & 0.9 & 0.01 & 0.95 \\
\hline Stomach & 0.6 & - & 0.9 & 1 & 0.2 & 0.9 & 0.00 & 0.99 & 0.84 & 0.03 \\
\hline Colon & 0.99 & 0.98 & - & 0.99 & 0.011 & 0.33 & 0.00 & 1 & 0.16 & 0.49 \\
\hline Rectum & 0.84 & 1 & 0.99 & - & 0.09 & 0.8 & 0.00 & 1 & 0.5 & 0.09 \\
\hline Larynx & 0.00 & 0.26 & 0.01 & 0.09 & - & 0.97 & 0.00 & 0.01 & 0.9 & 0.00 \\
\hline Over & 0.04 & 0.9 & 0.3 & 0.8 & 0.9 & - & 0.00 & 0.38 & 1 & 0.00 \\
\hline Endometrium & 0.00 & 0.00 & 0.00 & 0.00 & 0.00 & 0.00 & - & 0.00 & 0.00 & 0.00 \\
\hline Lung & 0.99 & 0.99 & 1 & 1 & 0.012 & 0.38 & 0.00 & - & 0.18 & 0.33 \\
\hline Breast & 0.01 & 0.8 & 0.16 & 0.57 & 0.99 & 1 & 0.00 & 0.18 & - & 0.00 \\
\hline Lymphoma & 0.95 & 0.03 & 0.49 & 0.09 & 0.00 & 0.00 & 0.00 & 0.33 & 0.00 & - \\
\hline
\end{tabular}

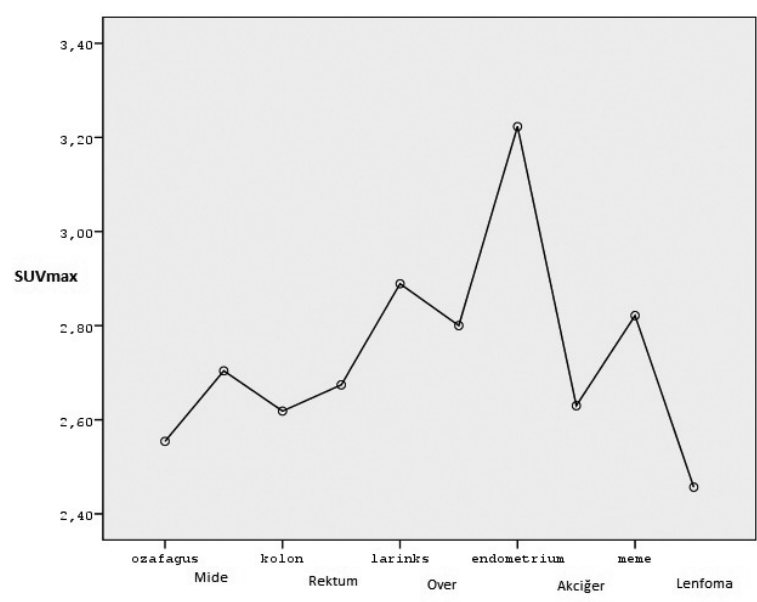

Figure 3. Mean SUV ${ }_{\text {max }}$ measurements of ROIs plotted on the right lobe of liver according to diagnosis

SUV: standard uptake value, ROI: region of interest

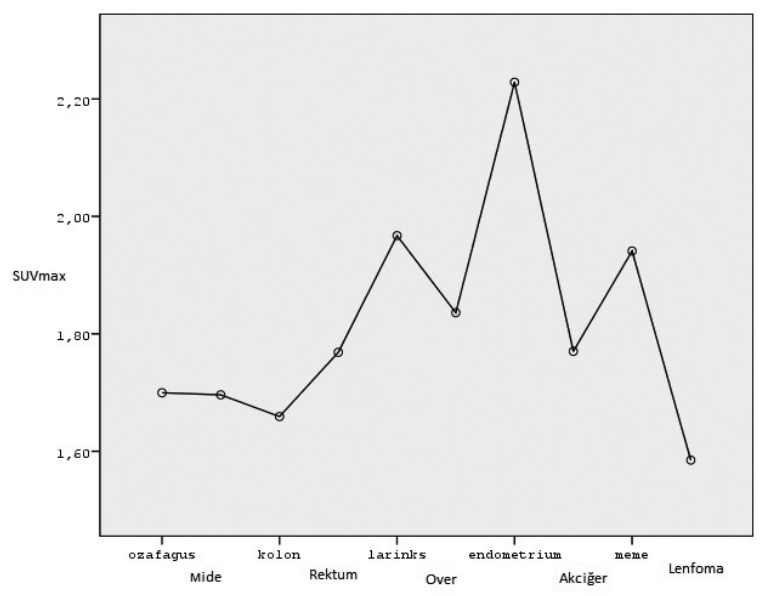

Figure 5. Mean SUV ${ }_{\text {max }}$ measurements of ROIs plotted on aortic arch according to diagnosis

SUV: standard uptake value, ROI: region of interest

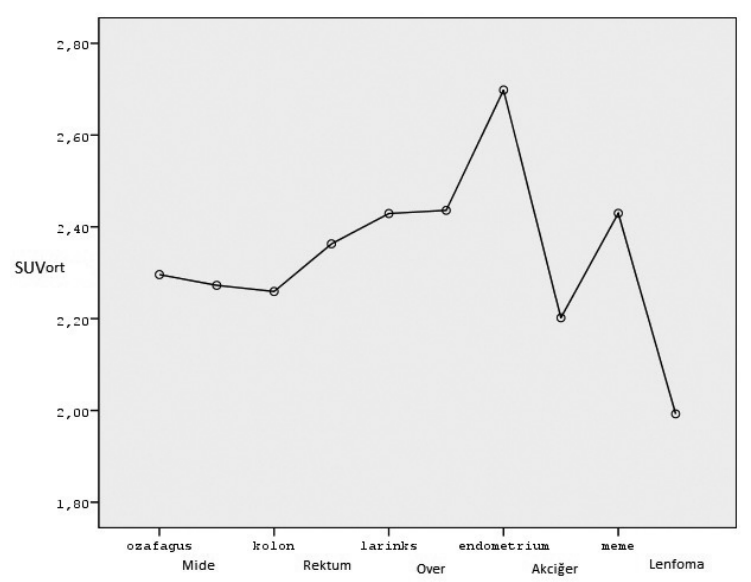

Figure 4. Mean SUV ${ }_{\text {mean }}$ measurements of ROIs plotted on the right lobe of liver according to diagnosis

SUV: standard uptake value, ROI: region of interest

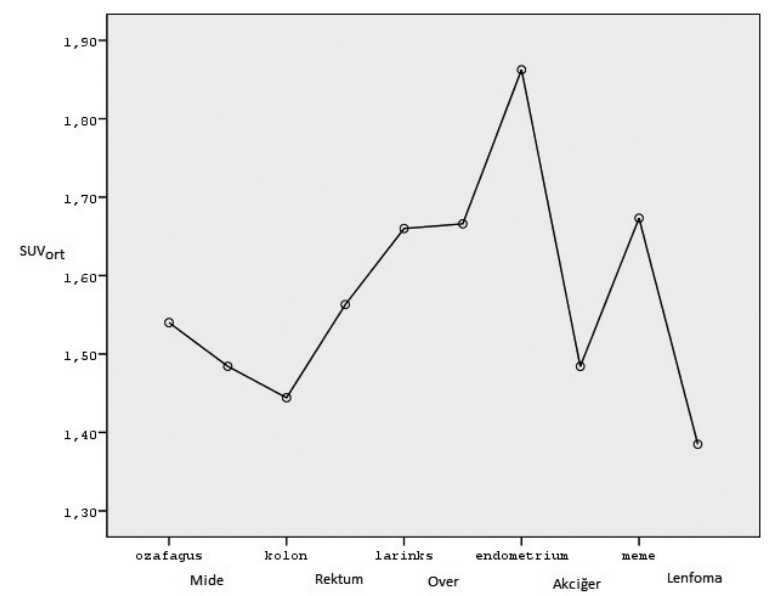

Figure 6. Mean SUV ${ }_{\text {mean }}$ measurements of ROIs plotted on aortic arch according to diagnosis

SUV: standard uptake value, ROI: region of interest 
The SUV varies depending on many factors. Imaging time, patient's $\mathrm{BMI}$, reconstruction parameters and resolution of the device are among these $(2,3,6-8)$. Numerous studies have been conducted on the effects of imaging time on SUV (9). In a study by Boellaard et al. (10) in 2004, they showed that many technical factors such as image reconstruction parameters and ROI might have a significant effect on SUV results. Another study evaluated SUV variability and the effect of various SUV measurements on treatment response in the event of repeated imaging (11). In a multicenter study conducted by Westerterp et al. (12), they evaluated FDG-PET studies by focusing on the inter-center methodological variability and showed the need for standardization of FDG-PET between centers. Some physiological factors affecting SUV include plasma glucose level during FDG-PET scan, FDG plasma clearance, scan period and patient movement. Since FDG uptake is time dependent, the time interval between FDG administration and PET scan will also affect the SUV. Therefore, it increases with the prolongation of the time to imaging after FDG injection. In our study, patients were randomized in order to prevent the difference that would occur due to the time elapsed after the injection (2).

The SUV is a numerical parameter that helps visualization in the diagnosis of oncologic patients and especially in evaluating response to treatment. In our study, we determined the normal range of SUV according to patient diagnoses. For this purpose, we evaluated two reference areas. In the study conducted in 531 patients, the mean SUV ${ }_{\max }$ was $2.7 \pm 0.2$ for liver and $1.8 \pm 0.2$ for BP. When the patients were grouped according to their diagnosis, statistically significant differences were

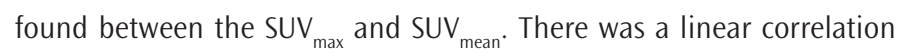
between liver SUV changes and BP SUV changes. SUV ratios of reference areas were $1.50 \pm 0.05$ in all patients. According to their diagnosis, the SUV $_{\text {max }}$ and SUV ${ }_{\text {mean }}$ range of the patients were determined. Liver and BP SUV changes of patients with endometrial carcinoma were significantly different between all other groups $(p=0.00)$. However, the ratio did not change since the rate of BP SUV changes was also high.

When SUV changes were examined, a statistical variation was found for liver and BP in patients with different diagnoses. This variation constitutes a physiological limit. This baseline range was defined in the study. In a similar study by Boktor et al. (13), a variation range was also defined. In this study, SUV changes with recurrent PET/CT scans were evaluated.

Knowing baseline SUV variations of patients prior to treatment makes an important contribution in determining pathological F-18 FDG involvement areas and in evaluating tumor response.

\section{Conclusion}

SUV measurements are currently the most appropriate method for the quantitative assessment of changes in metabolic activity. However, it is important to understand the limitations of these measurements and to minimize the effects of variables that can be controlled. It was concluded that the obtained SUV ranges might provide ease of application in the clinic in the evaluation of quantitative tumor response and comparison of tumor/background ratios in cancer patients.

\section{Ethics Committee Approval: Retrospective study.}

Informed Consent: Written consent was obtained from the patients themselves.

Peer-review: Externally peer-reviewed.

Author Contributions: Surgical and Medical Practices - Y.P., D.G.; Concept - Y.P.; Design - Y.P.; Data Collection and/ or Processing - Y.P., D.G.; Analysis and/or Interpretation - Y.P., D.G., G.G., E.S.; Literature Search Y.P.; Writing Manuscript - Y.P., G.M., G.G., E.S.

Conflict of Interest: No conflict of interest was declared by the authors.

Financial Disclosure: The authors declared that this study received no financial support.

\section{References}

1. Wampla S, Rauscha I, Weidingerb T, Beyera T, Gröschlc M, Gonzaleza JC. Quantification accuracy of neuro-oncology PET data as a function of emission scan duration in PET/MR compared to PET/CT. European Journal of Radiology 2017; 95: 257-64.

2. Kocabaş B. Onkolojik vakalarda $2 d$ ve $3 d$ modunda yapılan PET/BT görüntülemede SUV değerlerinin karșılaștırılması, Uzmanlık Tezi, Ankara 2008.

3. Thie JA. Understanding the standardized uptake value, its methods, and implications for usage. J Nucl Med 2004; 45: 1431-34.

4. Şanlı Y, Tekin BO, Tokmak H, Bozkurt F, Töre G, Bekiş R, et al. Türkiye Nükleer Tıp Derneği Nükleer Onkoloji Çalıșma Grubu. F18-FDG PET/BT ile onkolojik görüntüleme uygulama kılavuzu. www.tsnm.org/assets/images/files

5. Chin BB, Green ED, Turkington TG, Hawk TC, Coleman RE. Increasing uptake time in FDG-PET: standardized uptake values in normal tissues at 1 versus 3 h. Mol Imaging Biol 2009; 11: 118-22.

6. Heuscha P, Buchbendera C, Beiderwellenb K, Nensab F, Knemeyerc VH Lauensteinb et al. Standardized uptake values for (18F) FDG in normal organ tissues: Comparison of whole-body PET/CT and PET/MRI. European Journal of Radiology 2013; 82: 870-6.

7. Yan J, Chu-Shern JL, Loi HY, Khor LK, Sinha AK, Quek ST, et al. Impact of image reconstruction settings on texture features in 18F-FDG PET. J Nucl Med 2015; 56: $1667-73$.

8. Tahari AK, Paidpally V, Chirindel A, Wahl RL, Subramaniam RM. Two-TimePoint FDG PET/CT: Liver SULmean Repeatability. AJR Am J Roentgenol 2015; 204: 402-7.

9. Sonni I, Baratto L, Park S, Hatami N, Srinivas S, Davidzon G, et al. Initial experience with a SiPM-based PET/CT scanner: influence of acquisition time on image quality. EJNMMI Phys 2018; 5: 9.

10. Boellaard R, Krak NC, Hoekstra OS, Lammertsma AA. Effects of noise, image resolution, and ROI definition on the accuracy of standard uptake values: a simulation study. J Nucl Med 2004; 45: 1519-27.

11. Krak NC, Boellaard R, Hoekstra OS, Twisk Jos WR, Hoekstra CJ, Lammertsma AA. Effects of ROI definition and reconstruction method on quantitative outcome and applicability in a response monitoring trial Nanda C. Eur J Nucl Med Mol Imaging 2005; 32: 294-301.

12. Westerterp M, Pruim J, Oyen W, Hoekstra O, Paans A, Visser E, et al Quantification of FDG PET studies using standardised uptake values in multicentre trials: effects of image reconstruction, resolution and ROI definition parameters. Eur J Nucl Med Mol Imaging 2007; 34: 392-404.

13. Boktor RR, Walker G, Stacey R, Gledhill S, Pitman AG. Reference range for intrapatient variability in blood-pool and liver SUV for 18F-FDG PET. J Nucl Med 2013; 54: 677-82. 